\title{
“Sell in May and Go Away" Just Won’t Go Away
}

\author{
Sandro C. Andrade, Vidhi Chhaochharia, and Michael E. Fuerst
}

\begin{abstract}
The authors performed an out-of-sample test of the sell-in-May effect documented in previous research. Reducing equity exposure starting in May and levering it up starting in November persists as a profitable market-timing strategy. On average, stock returns are about 10 percentage points higher for NovemberApril half-year periods than for May-October half-year periods. The authors also found that the sell-in-May effect is pervasive in financial markets.
\end{abstract}

A multitude of calendar or seasonal anomalies from the efficient market hypothesis (EMH) have been identified: for example, the January effect, the holiday effect, the turn-ofthe-month effect, and such day-of-the-week effects as the Monday effect. However, as a predominantly nonexperimental field, financial economics is vulnerable to spurious inferences from data mining. In fact, many, if not most, calendar anomalies dissipate after they have been identified. Regarding the disappearance of the January effect, Eugene Fama is quoted as saying, "I think it was all chance to begin with. There are strange things in any body of data" (Smalhout 2000, p. 29).

Therefore, an objective test of a calendar effect must include a test of the effect's persistence using out-of-sample data. Sullivan, Timmermann, and White (2001), who addressed the dangers of data mining for calendar effects, noted, "New data provides an effective remedy against data mining. Use of new data ensures that the sample on which a hypothesis was originally based effectively is separated from the sample used to test the hypothesis" (p. 269).

In this study, we performed the first comprehensive out-of-sample analysis of the anomaly identified by the adage "Sell in May and go away," also known as the Halloween effect. In the first academic analysis of this effect, Bouman and Jacobsen (2002) studied 37 markets and found higher returns in 35 of these markets in the November-April half-year period than in the May-October half-year period; November-April returns were significantly higher in 20 of the 37 markets. Bouman and Jacobsen's sample ends in 1998. In our study, we investigated the out-of-sample 19982012 period for those 37 equity markets. ${ }^{1}$

Sandro C. Andrade is associate professor of finance, Vidhi Chhaochharia is associate professor of finance, and Michael E. Fuerst is lecturer of finance at the University of Miami, Coral Gables, Florida.
The sell-in-May effect is distinct among seasonal anomalies because it is the least affected by transaction costs. This fact is important because even if the anomaly is not a statistical fluke, it need not be a challenge to the EMH. To be meaningful, anomalies from the EMH must be exploitable trading opportunities net of transaction costs, a point that Jensen (1978), Fama (1991), and Rubinstein (2001) emphasized.

The requirement of exploitability net of costs is a weakness of several seasonal anomalies because the full exploitation of such anomalies requires frequent trading. For example, to fully exploit the turn-ofthe-month, Monday, and day-and-night effects, an investor would have to completely turn over a stock portfolio 12 times a year, 52 times a year, and 252 times a year, respectively. ${ }^{2}$ In contrast, the sell-inMay anomaly requires only two trades a year.

Discussion of findings. We found that the sellin-May effect not only persists but also maintains the same economic magnitude as in Bouman and Jacobsen's (2002) sample. On average across markets and over time, stock returns are roughly 10 percentage points (pps) higher in November-April half-year periods than in May-October half-year periods. This result is quite remarkable in light of the fate of most such calendar anomalies that are subjected to scrutiny after their discovery (see Dimson and Marsh 1999).

We also present novel evidence consistent with seasonal variation in aggregate risk aversion as the cause of the sell-in-May effect. We show that the sell-in-May effect is pervasive in financial markets; it is present across a wide variety of trading strategies that plausibly reap returns as compensation for aggregate risk taking. Specifically, we found an economically large and statistically significant sellin-May effect for strategies that exploit the value, size, credit risk, foreign exchange (FX) carry trade, and volatility risk premiums. 


\section{Data and Methodology}

We used MSCI stock market index total returns in local currencies for the 37 countries in Bouman and Jacobsen's (2002) sample. MSCI stock market index data begin in 1970 for 18 countries and in 1988 (or later) for 19 countries. We computed returns for adjacent half-year periods. MayOctober periods start at the beginning of May and end at the end of October, and NovemberApril periods start at the beginning of November and end at the end of April. The Bouman and Jacobsen sample period for each country begins in May of the year its MSCI index starts and ends in October 1998. Our out-of-sample period begins in November 1998 and ends in April 2012. Note that because we used half-year holding periods from May to October and from November to April, our sample periods must start in either May or November and end in either October or April. $^{3}$

Our core statistical analysis is based on the following regression equation:

$$
r_{i t}=\mu_{i}+\alpha S_{t}+\varepsilon_{i t},
$$

where

$r_{i t}=$ the return on the stock index for country $i$ for period $t$

$\mu_{i}=$ the intercept for country $i^{4}$

$\alpha=$ the sell-in-May coefficient to estimate

$S_{t}=$ a dummy variable that takes a value of 1 for November-April periods and 0 for May-October periods

$\varepsilon_{i t}=$ the error term

Equation 1 is estimated both country by country and across countries using pooled data. Additionally, we estimated Equation 1 using MSCI World Index returns in local currencies. In contrast to using individual country data and equally weighting across countries, using MSCI World returns value weights the returns and assigns larger weights to countries with larger market capitalizations.

\section{Country-by-Country Results}

Table 1 provides country-by-country mean returns for May-October and November-April periods and an ordinary least-squares (OLS) estimate of the sell-in-May coefficient $\alpha$ in Equation 1. Note that OLS estimates of this coefficient are algebraically identical to differences in mean returns between the November-April and May-October periods. Owing to evidence of first-order autocorrelation of residuals in most countries, we report $t$-statistics computed using Newey-West standard errors with one lag.
Table 1 displays results in two panels: Panel A shows results for countries whose MSCI data begin in 1970, and Panel B shows the results for countries whose MSCI data begin in 1988 or later (as described in the table notes). Each panel shows the results for both the Bouman and Jacobsen (2002) sample period ending in October 1998 and the subsequent out-ofsample period beginning in November 1998.

Strikingly, Table 1 shows that the mean return for November-April is larger than the mean return for May-October in all 37 countries for the out-ofsample period; that is, the sell-in-May effect persists out of sample. In addition, we confirmed Bouman and Jacobsen's results for their sample period and found a sell-in-May effect in 35 of the 37 countries. In total, 13 of the 37 countries had significantly greater returns for November-April out of sample, compared with 19 of 37 countries for Bouman and Jacobsen's sample period. Note, however, that the average number of half-year periods in Bouman and Jacobsen's sample period is 38 whereas it is only 27 in the out-of-sample period. Therefore, it is not surprising to find noisier point estimates in the out-of-sample period.

One caveat applies to the results in Table 1. For the out-of-sample data, we calculated the difference between two sample means with a sample size of only 14 . The small sample size potentially led to spurious results for individual countries. We mitigated the small-sample problem by pooling data across all countries from Table 1 and performing a test of normality of residuals to verify whether outliers unduly influence results (see Table 2).

\section{Pooled and Value-Weighted Results}

Panel A of Table 2 contains the main results of our study. It shows pooled estimates of the sell-in-May coefficient $\alpha$ in Equation 1 for three samples. The first column provides the results for all 37 countries for Bouman and Jacobsen's sample period. In light of the results in Table 1, we removed Brazil and Argentina from the sample; these results are presented in the second column. ${ }^{5}$ In the third column, we present our novel out-of-sample results.

For robustness, we present a number of different pooled estimates for the sell-in-May coefficient $\alpha$ in Equation 1. The equation is estimated using either OLS or Prais-Winsten feasible generalized least squares (FGLS), both with and without fixed effects (i.e., a different intercept for each market). ${ }^{6}$ Moreover, we report three types of robust standard errors in the OLS specifications: (1) panel-corrected standard errors (PCSEs), (2) Newey-West standard errors with one lag, and (3) Driscoll-Kraay 
Table 1. Country-by-Country Statistics by Sample Period ( $t$-statistics in parentheses)

\begin{tabular}{|c|c|c|c|c|c|c|c|c|c|c|}
\hline \multirow[b]{2}{*}{$\underline{\text { Market }}$} & \multicolumn{5}{|c|}{$\begin{array}{c}\text { Bouman and Jacobsen (2002) Sample Period } \\
\text { May 1970-October } 1998\end{array}$} & \multicolumn{5}{|c|}{$\begin{array}{c}\text { Out of Sample } \\
\text { November 1998-April } 2012 \\
\end{array}$} \\
\hline & $N$ & Overall & May-Oct. & Nov.-Apr. & $\begin{array}{l}\text { Sell-in- } \\
\text { May } \\
\text { Effect }\end{array}$ & $N$ & Overall & May-Oct. & Nov.-Apr. & $\begin{array}{c}\text { Sell-in- } \\
\text { May } \\
\text { Effect }\end{array}$ \\
\hline \multicolumn{11}{|c|}{ A. MSCI data begin in 1970} \\
\hline Australia & 57 & $\begin{array}{c}6.53 \\
(3.31)\end{array}$ & 3.56 & 9.61 & $\begin{array}{c}6.05 \\
(1.68)\end{array}$ & 27 & $\begin{array}{c}4.53 \\
(1.93)\end{array}$ & 2.37 & 6.55 & $\begin{array}{r}4.18 \\
(1.09)\end{array}$ \\
\hline Austria & 57 & $\begin{array}{c}5.17 \\
(2.27)\end{array}$ & 0.00 & 10.53 & $\begin{array}{l}10.53 \\
(2.56)\end{array}$ & 27 & $\begin{array}{l}3.50 \\
(0.84)\end{array}$ & -3.14 & 9.67 & $\begin{array}{l}12.81 \\
(1.94)\end{array}$ \\
\hline Belgium & 57 & $\begin{array}{c}8.23 \\
(4.70)\end{array}$ & 0.61 & 16.12 & $\begin{array}{l}\mathbf{1 5 . 5 1} \\
(5.55)\end{array}$ & 27 & $\begin{array}{l}1.84 \\
(0.49)\end{array}$ & -0.91 & 4.39 & $\begin{array}{r}5.30 \\
(0.84)\end{array}$ \\
\hline Canada & 57 & $\begin{array}{c}6.07 \\
(3.88)\end{array}$ & 2.49 & 9.78 & $\begin{array}{c}7.29 \\
(2.61)\end{array}$ & 27 & $\begin{array}{c}4.85 \\
(1.70)\end{array}$ & 1.37 & 8.08 & $\begin{array}{c}6.71 \\
(1.52)\end{array}$ \\
\hline Denmark & 57 & $\begin{array}{c}8.09 \\
(3.23)\end{array}$ & 7.04 & 9.20 & $\begin{array}{c}2.16 \\
(0.62)\end{array}$ & 27 & $\begin{array}{c}5.90 \\
(1.71)\end{array}$ & 1.20 & 10.26 & $\begin{array}{c}9.06 \\
(1.76)\end{array}$ \\
\hline France & 57 & $\begin{array}{c}8.00 \\
(3.52)\end{array}$ & 0.30 & 15.97 & $\begin{array}{l}15.67 \\
(3.42)\end{array}$ & 27 & $\begin{array}{l}2.46 \\
(0.73)\end{array}$ & -1.33 & 5.99 & $\begin{array}{c}7.32 \\
(1.64)\end{array}$ \\
\hline Germany & 57 & $\begin{array}{c}5.89 \\
(3.00)\end{array}$ & 1.22 & 10.74 & $\begin{array}{c}9.52 \\
(2.74)\end{array}$ & 27 & $\begin{array}{l}3.00 \\
(0.85)\end{array}$ & -2.70 & 8.30 & $\begin{array}{l}\mathbf{1 1 . 0 0} \\
(1.97)\end{array}$ \\
\hline Hong Kong & 57 & $\begin{array}{l}12.20 \\
(3.76)\end{array}$ & 10.83 & 13.61 & $\begin{array}{c}2.78 \\
(0.41)\end{array}$ & 27 & $\begin{array}{c}6.08 \\
(1.61)\end{array}$ & 3.27 & 8.68 & $\begin{array}{c}5.41 \\
(0.63)\end{array}$ \\
\hline Italy & 57 & $\begin{array}{c}8.17 \\
(2.45)\end{array}$ & -0.32 & 16.40 & $\begin{array}{l}16.72 \\
(3.33)\end{array}$ & 27 & $\begin{array}{c}0.72 \\
(0.23)\end{array}$ & -3.97 & 5.07 & $\begin{array}{c}9.04 \\
(1.81)\end{array}$ \\
\hline Japan & 57 & $\begin{array}{c}5.47 \\
(2.60)\end{array}$ & -0.03 & 11.16 & $\begin{array}{l}11.19 \\
(3.26)\end{array}$ & 27 & $\begin{array}{l}1.00 \\
(0.29)\end{array}$ & -4.53 & 6.13 & $\begin{array}{l}\mathbf{1 0 . 6 6} \\
(1.95)\end{array}$ \\
\hline Netherlands & 57 & $\begin{array}{c}7.92 \\
(4.64)\end{array}$ & 1.56 & 14.52 & $\begin{array}{l}\mathbf{1 2 . 9 6} \\
(4.12)\end{array}$ & 27 & $\begin{array}{l}2.20 \\
(0.64)\end{array}$ & -2.35 & 6.43 & $\begin{array}{c}8.78 \\
(1.65)\end{array}$ \\
\hline Norway & 57 & $\begin{array}{c}7.86 \\
(2.59)\end{array}$ & 3.69 & 12.19 & $\begin{array}{c}8.50 \\
(1.52)\end{array}$ & 27 & $\begin{array}{c}6.31 \\
(1.66)\end{array}$ & 2.39 & 9.95 & $\begin{array}{c}7.56 \\
(1.18)\end{array}$ \\
\hline Singapore & 57 & $\begin{array}{c}6.95 \\
(2.45)\end{array}$ & 1.59 & 12.50 & $\begin{array}{l}\mathbf{1 0 . 9 1} \\
(1.93)\end{array}$ & 27 & $\begin{array}{c}6.84 \\
(1.53)\end{array}$ & 3.17 & 10.26 & $\begin{array}{c}7.09 \\
(0.91)\end{array}$ \\
\hline Spain & 57 & $\begin{array}{c}8.32 \\
(3.11)\end{array}$ & 1.98 & 14.89 & $\begin{array}{l}12.91 \\
(2.97)\end{array}$ & 27 & $\begin{array}{c}2.46 \\
(0.78)\end{array}$ & 0.84 & 3.96 & $\begin{array}{c}3.12 \\
(0.53)\end{array}$ \\
\hline Sweden & 57 & $\begin{array}{l}\mathbf{1 0 . 7 1} \\
(3.75)\end{array}$ & 2.94 & 18.75 & $\begin{array}{l}\mathbf{1 5 . 8 1} \\
(3.44)\end{array}$ & 27 & $\begin{array}{c}6.09 \\
(1.31)\end{array}$ & -2.42 & 14.01 & $\begin{array}{l}16.43 \\
(2.60)\end{array}$ \\
\hline Switzerland & 57 & $\begin{array}{c}6.06 \\
(3.57)\end{array}$ & 2.19 & 10.08 & $\begin{array}{c}7.89 \\
(2.44)\end{array}$ & 27 & $\begin{array}{l}1.79 \\
(0.69)\end{array}$ & -1.12 & 4.49 & $\begin{array}{c}5.61 \\
(1.32)\end{array}$ \\
\hline $\begin{array}{l}\text { United } \\
\text { Kingdom }\end{array}$ & 57 & $\begin{array}{c}9.05 \\
(4.34)\end{array}$ & 2.00 & 16.34 & $\begin{array}{l}14.34 \\
(3.12)\end{array}$ & 27 & $\begin{array}{r}2.53 \\
(1.08)\end{array}$ & -0.59 & 5.42 & $\begin{array}{c}6.01 \\
(1.60)\end{array}$ \\
\hline United States & 57 & $\begin{array}{c}6.90 \\
(5.18)\end{array}$ & 3.84 & 10.08 & $\begin{array}{c}6.24 \\
(2.48)\end{array}$ & 27 & $\begin{array}{c}2.52 \\
(0.96)\end{array}$ & -1.03 & 5.83 & $\begin{array}{c}6.86 \\
(1.77)\end{array}$ \\
\hline \multicolumn{11}{|c|}{ B. MSCI data begin in 1988 or later } \\
\hline Argentina & 21 & $\begin{array}{r}200.2 \\
(1.43)\end{array}$ & 293.57 & 97.55 & $\begin{array}{r}-196.02 \\
(-0.88)\end{array}$ & 27 & $\begin{array}{l}\mathbf{1 1 . 9 4} \\
(1.75)\end{array}$ & 7.58 & 15.99 & $\begin{array}{c}8.41 \\
(0.60)\end{array}$ \\
\hline Brazil & 17 & $\begin{array}{r}198.1 \\
(2.52)\end{array}$ & 143.31 & 259.77 & $\begin{array}{r}116.46 \\
(1.34)\end{array}$ & 27 & $\begin{array}{l}\mathbf{1 2 . 3 4} \\
(3.21)\end{array}$ & 6.92 & 17.37 & $\begin{array}{l}10.45 \\
(1.34)\end{array}$ \\
\hline
\end{tabular}

(continued) 
Table 1. Country-by-Country Statistics by Sample Period (continued) ( $t$-statistics in parentheses)

\begin{tabular}{|c|c|c|c|c|c|c|c|c|c|c|}
\hline \multirow[b]{2}{*}{ Market } & \multicolumn{5}{|c|}{$\begin{array}{c}\text { Bouman and Jacobsen (2002) Sample Period } \\
\text { May 1970-October } 1998\end{array}$} & \multicolumn{5}{|c|}{$\begin{array}{c}\text { Out of Sample } \\
\text { November 1998-April } 2012\end{array}$} \\
\hline & $N$ & Overall & May-Oct. & Nov.-Apr. & $\begin{array}{c}\text { Sell-in- } \\
\text { May } \\
\text { Effect }\end{array}$ & $N$ & Overall & May-Oct. & Nov.-Apr. & $\begin{array}{c}\text { Sell-in- } \\
\text { May } \\
\text { Effect }\end{array}$ \\
\hline Chile & 21 & $\begin{array}{l}17.83 \\
(2.49)\end{array}$ & 12.08 & 24.15 & $\begin{array}{l}12.07 \\
(1.08)\end{array}$ & 27 & $\begin{array}{c}8.63 \\
(3.09)\end{array}$ & 7.27 & 9.89 & $\begin{array}{c}2.62 \\
(0.51)\end{array}$ \\
\hline Finland & 21 & $\begin{array}{c}10.28 \\
(1.82)\end{array}$ & 3.72 & 17.49 & $\begin{array}{l}13.77 \\
(1.63)\end{array}$ & 27 & $\begin{array}{c}4.78 \\
(0.72)\end{array}$ & -3.70 & 12.66 & $\begin{array}{l}\mathbf{1 6 . 3 6} \\
(1.79)\end{array}$ \\
\hline Greece & 21 & $\begin{array}{l}17.81 \\
(2.12)\end{array}$ & 7.74 & 28.89 & $\begin{array}{l}21.15 \\
(1.44)\end{array}$ & 27 & $\begin{array}{l}-1.29 \\
(-0.22)\end{array}$ & -2.97 & 0.27 & $\begin{array}{c}3.24 \\
(0.38)\end{array}$ \\
\hline Indonesia & 21 & $\begin{array}{l}13.36 \\
(1.26)\end{array}$ & 5.33 & 22.20 & $\begin{array}{l}16.87 \\
(1.19)\end{array}$ & 27 & $\begin{array}{l}16.07 \\
(2.64)\end{array}$ & 7.83 & 23.73 & $\begin{array}{l}15.90 \\
(1.45)\end{array}$ \\
\hline Ireland & 21 & $\begin{array}{c}7.89 \\
(2.24)\end{array}$ & 1.03 & 16.04 & $\begin{array}{l}15.01 \\
(2.15)\end{array}$ & 27 & $\begin{array}{l}-0.76 \\
(-0.19)\end{array}$ & -10.03 & 7.85 & $\begin{array}{l}\mathbf{1 7 . 8 8} \\
(3.08)\end{array}$ \\
\hline Jordan & 21 & $\begin{array}{c}3.81 \\
(1.45)\end{array}$ & 0.07 & 7.93 & $\begin{array}{c}7.86 \\
(1.72)\end{array}$ & 27 & $\begin{array}{c}5.22 \\
(1.06)\end{array}$ & 2.93 & 7.35 & $\begin{array}{c}4.42 \\
(0.75)\end{array}$ \\
\hline Malaysia & 21 & $\begin{array}{l}3.57 \\
(0.76)\end{array}$ & -1.21 & 8.83 & $\begin{array}{l}10.04 \\
(1.46)\end{array}$ & 27 & $\begin{array}{c}8.89 \\
(2.09)\end{array}$ & 3.67 & 13.74 & $\begin{array}{l}10.07 \\
(1.30)\end{array}$ \\
\hline Mexico & 21 & $\begin{array}{l}21.73 \\
(3.81)\end{array}$ & 21.21 & 22.29 & $\begin{array}{c}1.08 \\
(0.14)\end{array}$ & 27 & $\begin{array}{l}10.20 \\
(3.14)\end{array}$ & 5.85 & 14.24 & $\begin{array}{r}8.39 \\
(1.44)\end{array}$ \\
\hline New Zealand & 21 & $\begin{array}{c}3.36 \\
(1.01)\end{array}$ & 4.90 & 1.66 & $\begin{array}{c}-3.24 \\
(-0.56)\end{array}$ & 27 & $\begin{array}{c}3.32 \\
(1.56)\end{array}$ & -1.38 & 7.68 & $\begin{array}{c}9.06 \\
(2.29)\end{array}$ \\
\hline Philippines & 21 & $\begin{array}{l}\mathbf{1 1 . 4 2} \\
(1.85)\end{array}$ & 7.24 & 16.03 & $\begin{array}{c}8.79 \\
(0.66)\end{array}$ & 27 & $\begin{array}{c}5.73 \\
(1.40)\end{array}$ & 3.16 & 8.11 & $\begin{array}{r}4.95 \\
(0.63)\end{array}$ \\
\hline Portugal & 21 & $\begin{array}{c}7.71 \\
(1.51)\end{array}$ & 2.28 & 13.68 & $\begin{array}{l}11.40 \\
(1.25)\end{array}$ & 27 & $\begin{array}{c}0.36 \\
(0.11)\end{array}$ & -2.60 & 3.12 & $\begin{array}{c}5.72 \\
(1.04)\end{array}$ \\
\hline Russia & 7 & $\begin{array}{l}22.99 \\
(0.90)\end{array}$ & 15.22 & 33.35 & $\begin{array}{l}18.13 \\
(0.58)\end{array}$ & 27 & $\begin{array}{c}16.52 \\
(2.41)\end{array}$ & 3.10 & 28.99 & $\begin{array}{r}25.89 \\
(1.87)\end{array}$ \\
\hline South Africa & 11 & $\begin{array}{c}6.36 \\
(1.40)\end{array}$ & -2.76 & 17.29 & $\begin{array}{l}20.05 \\
(2.13)\end{array}$ & 27 & $\begin{array}{c}9.10 \\
(3.31)\end{array}$ & 6.33 & 11.68 & $\begin{array}{c}5.35 \\
(0.90)\end{array}$ \\
\hline South Korea & 21 & $\begin{array}{c}0.66 \\
(0.16)\end{array}$ & -0.44 & 1.88 & $\begin{array}{c}2.32 \\
(0.29)\end{array}$ & 27 & $\begin{array}{l}11.68 \\
(2.21)\end{array}$ & 1.17 & 21.43 & $\begin{array}{c}20.26 \\
(1.90)\end{array}$ \\
\hline Taiwan & 21 & $\begin{array}{c}7.48 \\
(1.37)\end{array}$ & -5.15 & 21.37 & $\begin{array}{c}26.52 \\
(1.99)\end{array}$ & 27 & $\begin{array}{c}3.52 \\
(0.95)\end{array}$ & -1.80 & 8.46 & $\begin{array}{l}10.26 \\
(1.13)\end{array}$ \\
\hline Thailand & 21 & $\begin{array}{c}3.37 \\
(0.60)\end{array}$ & 0.78 & 6.21 & $\begin{array}{c}5.43 \\
(0.50)\end{array}$ & 27 & $\begin{array}{c}9.86 \\
(2.17)\end{array}$ & 2.87 & 16.34 & $\begin{array}{l}13.47 \\
(1.44)\end{array}$ \\
\hline Turkey & 21 & $\begin{array}{l}49.81 \\
(3.11)\end{array}$ & 45.96 & 54.05 & $\begin{array}{c}8.09 \\
(0.29)\end{array}$ & 27 & $\begin{array}{c}21.41 \\
(2.18)\end{array}$ & 8.59 & 33.32 & $\begin{array}{c}24.73 \\
(1.26)\end{array}$ \\
\hline
\end{tabular}

Notes: Table 1 contains a summary of country-by-country results for MSCI total index returns in local currencies for our two sample periods. Returns are expressed in percentages per half-year. The sell-in-May effect is defined as the half-year return for November-April minus the half-year return for May-October (expressed in pps). The $t$-statistics are calculated using Newey-West standard errors with one lag in a regression of half-year returns on a constant and a sell-in-May effect dummy variable that takes a value of 1 for November-April periods and 0 otherwise. $N$ is the total number of half-year periods in each sample period. Panel A displays the results for countries whose MSCI indices start in 1970. Panel B displays the results for countries whose MSCI indices start in 1988 except for Brazil (1990), South Africa (1993), and Russia (1995). Coefficients that are statistically significant at the $10 \%$ level in two-tailed tests are in bold. 
Table 2. Pooled Statistics by Sample Period for Stock Returns

( $t$-statistics in parentheses)

\begin{tabular}{|c|c|c|c|}
\hline & \multicolumn{3}{|c|}{ Bouman and Jacobsen (2002) } \\
\hline & $\begin{array}{l}\text { Bouman and Jacobsen } \\
\text { (2002) Sample Period }\end{array}$ & $\begin{array}{l}\text { Sample Period } \\
\text { excluding Argentina and Brazil }\end{array}$ & $\begin{array}{c}\text { Out of Sample: } \\
\text { Nov. 1998-Apr. } 2012\end{array}$ \\
\hline \multicolumn{4}{|c|}{ A. Dependent variable: Half-year stock returns in local currencies for individual markets } \\
\hline \multicolumn{4}{|c|}{ With market fixed effects } \\
\hline Sell-in-May effect & 8.71 & 10.46 & 9.74 \\
\hline PSCE & $(1.45)$ & $(3.47)$ & (1.69) \\
\hline Newey-West & $(2.35)$ & (9.99) & (7.52) \\
\hline Driscoll-Kraay & $(1.64)$ & (3.59) & (1.85) \\
\hline Sell-in-May effect & 9.06 & 10.36 & 9.28 \\
\hline Prais-Winsten PCSE & $(1.66)$ & $(3.90)$ & $(2.00)$ \\
\hline \multicolumn{4}{|l|}{ Without market fixed effects } \\
\hline Sell-in-May effect & 8.38 & 10.52 & 9.74 \\
\hline PSCE & $(1.40)$ & (3.50) & (1.69) \\
\hline Newey-West & (2.26) & (9.92) & (7.63) \\
\hline Driscoll-Kraay & $(1.56)$ & (3.64) & (1.85) \\
\hline Sell-in-May effect & 8.69 & 10.07 & 9.22 \\
\hline Prais-Winsten PCSE & (1.85) & $(3.79)$ & $(2.07)$ \\
\hline No. of markets & 37 & 35 & 37 \\
\hline No. of observations & 1,397 & 1,359 & 999 \\
\hline Average no. of observations per market & 37.8 & 38.8 & 27 \\
\hline Minimum no. of observations per market & 7 & 7 & 27 \\
\hline Maximum no. of observations per market & 57 & 57 & 27 \\
\hline \multicolumn{4}{|c|}{ B. Dependent variable: MSCI World half-year returns } \\
\hline Sell-in-May effect & 8.68 & & 7.57 \\
\hline Newey-West & $(3.50)$ & & $(1.93)$ \\
\hline $\begin{array}{l}P \text {-value of test of autocorrelation of } \\
\text { residuals }\end{array}$ & 0.704 & & 0.084 \\
\hline$P$-value of test of normality of residuals & 0.416 & & 0.417 \\
\hline Sell-in-May effect & 8.67 & & 7.17 \\
\hline Prais-Winsten, robust & (3.58) & & (2.14) \\
\hline No. of observations & 57 & & 27 \\
\hline
\end{tabular}

Notes: Table 2 contains aggregate estimates of the sell-in-May effect for global stock returns, defined as the average difference in return between the November-April and May-October periods (expressed in pps). Panel A pools 37 country-level total returns for MSCI indices in local currencies. Panel B uses MSCI World Index returns. In both panels, we report results of regressions in which the dependent variable is the half-year return and the independent variable is a sell-in-May effect dummy variable that takes a value of 1 for November-April periods and 0 otherwise. Panel A displays results of regressions both with and without market fixed effects. There are three sample periods: (1) the Bouman and Jacobsen (2002) sample period, which ends in October 1998 for all markets, (2) the Bouman and Jacobsen (2002) sample period without hyperinflation countries (Brazil and Argentina), and (3) the out-of-sample period November 1998-April 2012 for all markets. Our regressions are either OLS or Prais-Winsten AR(1) regressions. The standard errors of OLS regressions are either panel corrected (no autocorrelation), Newey-West with one lag (no cross-market correlations), or Driscoll-Kraay with one lag. The standard errors of Prais-Winsten regressions are panel-corrected standard errors. Coefficients that are statistically significant at the $10 \%$ level in two-tailed tests (across all types of standard errors) are in bold.

standard errors with one lag, which is our preferred choice. ${ }^{7}$ In the FGLS specifications, we report panelcorrected standard errors.

Panel A of Table 2 shows, across all estimation methods, an economically large and statistically significant sell-in-May effect in the out-of-sample period. The out-of-sample coefficient estimates range from $9.22 \mathrm{pps}$ in the Prais-Winsten specification without market fixed effects to 9.74 pps in the OLS estimation with market fixed effects.

The economic magnitude of the sell-in-May effect estimated for the out-of-sample period is very 
close to that estimated for the Bouman and Jacobsen sample period. For Bouman and Jacobsen's sample period including Brazil and Argentina, the sell-inMay effect estimates range from 8.38 pps to $9.06 \mathrm{pps}$. For the sample excluding Brazil and Argentina, the sell-in-May effect estimates range from 10.07 pps to 10.52 pps and all coefficient estimates are statistically significant at the $10 \%$ level.

Panel B of Table 2 provides estimates of the sell-in-May effect using MSCI World Index returns instead of country-level index returns. At any point in time, the MSCI World Index is a value-weighted index of up to 24 developed markets (and thus does not include any of the emerging markets in the list of 37 countries in Table 1). We present results for both Bouman and Jacobsen's sample period and our out-of-sample period using both OLS and Prais-Winsten FGLS estimations.

Panel B of Table 2 shows an economically large and statistically significant sell-in-May effect for out-of-sample MSCI World Index returns. The coefficient estimates are 7.17 pps for the PraisWinsten FGLS estimation and 7.57 pps for the OLS estimation; both coefficients are statistically significant at the $10 \%$ level. The sell-in-May coefficient estimates in Bouman and Jacobsen's sample period are $8.68 \mathrm{pps}$ and $8.67 \mathrm{pps}$. These results corroborate the pooled estimates in Panel A of Table 2; using MSCI World Index returns, we found that the economic magnitude of the sell-in-May effect is similar for both in-sample and out-of-sample estimates. $^{8}$

Figure 1 illustrates the sell-in-May effect over time. It shows yearly differences between returns for November-April periods and returns for the previous May-October periods. The figure shows results averaged across the countries in Panel A of Table 1 (equally weighted) and results using the MSCI World Index (value weighted). The noise in returns notwithstanding, the figure indicates that the sell-in-May effect persists beyond Bouman and Jacobsen's original sample. As in the original sample, stock returns tend to be higher in NovemberApril than in May-October.

\section{Trading Strategy}

Table 3 shows an alternative way of evaluating the economic significance of the sell-in-May effect. We compared the performance of a passive buyand-hold equity investing strategy with the performance of market-timing strategies designed to exploit the sell-in-May effect. The strategies differ by the degree of aggressiveness in exploiting the sell-in-May effect and the extent to which they are (on average over time) fully invested in equities. Importantly, we ensured that both the passive and the active strategies are viable, investable trading strategies associated with extremely liquid securities. ${ }^{9}$

Figure 1. The Sell-in-May Effect over Time

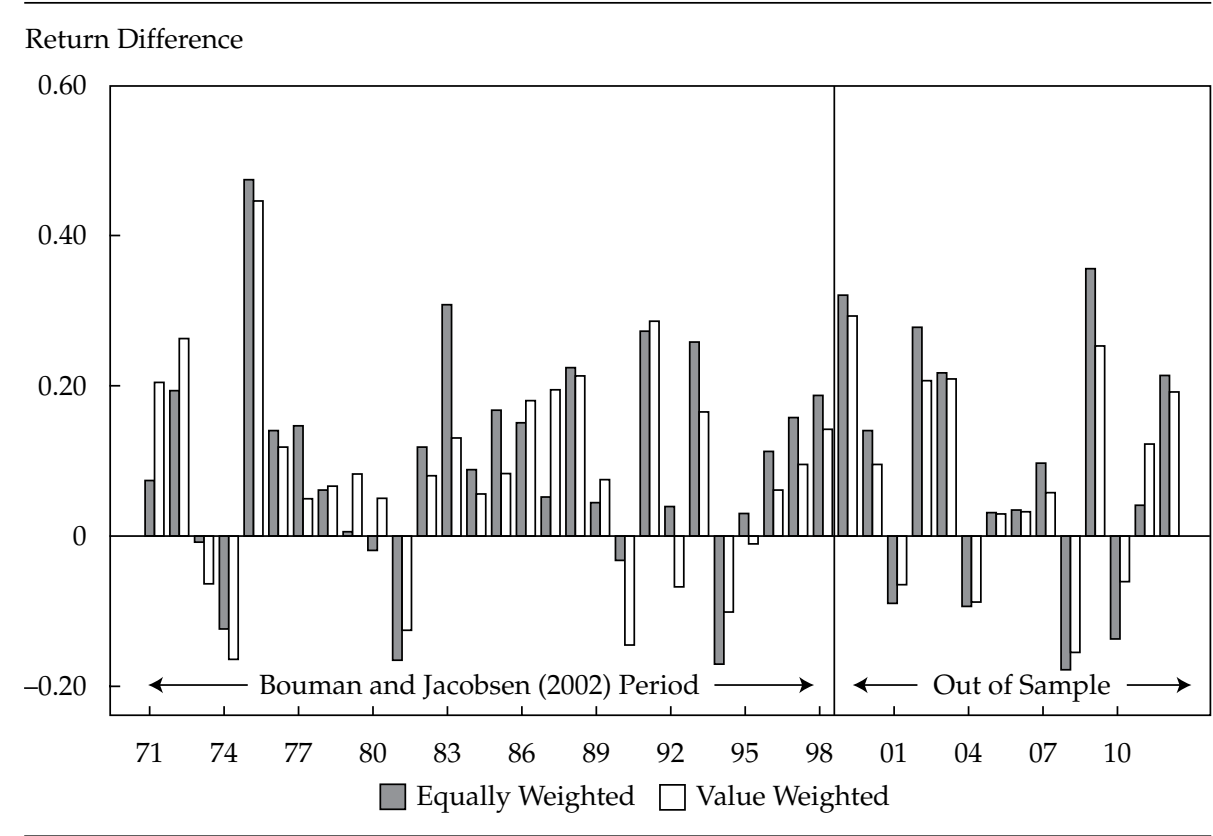

Notes: This figure shows the differences between November-April stock returns and the previous May-October stock returns for each year ending in April. "Equally Weighted" denotes the average of countries in Panel A of Table 1. "Value Weighted" denotes the MSCI World Index in local currencies. 
Table 3. Market-Timing Trading Strategies, May 1994-April 2012

(t-statistics in parentheses)

\begin{tabular}{lccccc}
\hline & \multicolumn{5}{c}{ Sell-in-May Timing Strategies } \\
& \multicolumn{5}{c}{ (May-Oct. S\&P 500 weight, Nov-Apr. S\&P 500 weight) } \\
\cline { 2 - 6 } & SPDR S\&P 500 ETF & $(0.75,1.25)$ & $(0.5,1.5)$ & $(0,2)$ & $(0,1)$ \\
\hline Panel A. & 4.79 & 5.47 & 6.15 & 7.50 & 4.64 \\
Average return & 3.24 & 3.92 & 4.60 & 5.95 & 3.09 \\
Average excess return & 11.50 & 11.46 & 12.12 & 15.09 & 7.57 \\
Standard deviation of returns & 0.40 & 0.48 & 0.54 & 0.56 & 0.58 \\
Sharpe ratio (annualized) & & & & & \\
Panel B. & 1 & 0.97 & 0.93 & 0.87 & 0.43 \\
CAPM beta & 0 & 0.79 & $\mathbf{1 . 5 7}$ & $\mathbf{3 . 1 4}$ & $\mathbf{1 . 6 9}$ \\
CAPM alpha & & $(2.04)$ & $(2.04)$ & $(2.04)$ & $(2.20)$ \\
& & & & & \\
Panel C. & 0 & $\mathbf{0 . 6 8}$ & $\mathbf{1 . 3 6}$ & $\mathbf{2 . 7 1}$ & -0.15 \\
Average active return & & $(1.86)$ & $(1.86)$ & $(1.86)$ & $(-0.11)$ \\
& & 2.87 & 5.75 & 11.50 & 8.61 \\
Tracking error & 0 & 0.34 & 0.34 & 0.34 & -0.02 \\
Information ratio (annualized) & & 36 & 36 & 36 & 36 \\
$N$ & 36 & & & & \\
$N$
\end{tabular}

Notes: Table 3 contains summary results of U.S. market-timing strategies that exploit the sell-in-May effect. Returns are expressed in percentages per half-year. The first column pertains to a passive strategy that holds the SPDR S\&P 500 ETF at all times. The Sharpe ratio is annualized by multiplying the Sharpe ratio calculated from half-year returns by the square root of 2 . The $t$-statistics in parentheses use Newey-West standard errors with one lag because of strong evidence of return autocorrelation. Coefficients that are statistically significant at the $10 \%$ level in two-tailed tests are in bold. CAPM stands for the capital asset pricing model.

The passive strategy is $100 \%$ invested in the SPDR S\&P 500 ETF at all times. In contrast, investments in the market-timing strategies vary over time. The market-timing strategies are denoted by $\left(w_{1}, w_{2}\right)$, where $w_{1}$ and $w_{2}$ represent the fraction of the total portfolio invested in equity securities in the May-October and November-April periods, respectively. The fraction not in equity securities is invested in one-month U.S. T-bills. In comparison, the passive strategy could be denoted by $(1,1)$ and all active strategies by $\left(w_{1}\right.$, $w_{2}$ ) with $w_{1}<w_{2}$. That is, timing strategies seek higher exposure in November-April periods than in May-October periods.

In addition to the passive strategy, three timing strategies- $(0.75,1.25),(0.5,1.5)$, and $(0,2)-$ are, on average over time, fully invested in equity securities. These strategies represent increasingly aggressive bets on a higher equity risk premium in November-April than in May-October. The remaining timing strategy- $(0,1)$-is, on average over time, underinvested in equity, and it represents a view that the May-October equity risk premium is not only smaller than the November-April premium but also "too small" in an absolute sense (i.e., relative to its own risk exposure).
The market-timing strategies $(0.75,1.25),(0.5$, $1.5)$, and $(0,2)$ invest in the SPDR S\&P 500 ETF and one-month T-bills and take long positions in S\&P 500 Index futures contracts to achieve leverage (i.e., to achieve $w_{2}>1$ ). The timing strategies are rebalanced twice a year as follows. At the end of April, a fraction of wealth, $w_{1}$, is invested in the SPDR S\&P 500 ETF and the remaining fraction, $1-w_{1}$, is invested in one-month T-bills. At the end of October, all wealth is invested in the SPDR S\&P 500 ETF and, to achieve the necessary leverage $\left(w_{2}-1\right)$, a long position of corresponding size in the S\&P 500 futures contract expiring in mid-June of the subsequent year is entered into. This long position is unwound at the end of April when the investment position is again rebalanced. ${ }^{10}$

Table 3 shows that sell-in-May market-timing strategies outperform the passive strategy. Panel A shows that the Sharpe ratios of timing strategies are higher than the Sharpe ratio of the passive strategy. The excess return of the passive strategy is equal to $3.24 \%$ per half-year, and its standard deviation of returns is equal to $11.50 \%$, leading to an annualized Sharpe ratio of 0.40 . The Sharpe ratios of the timing strategies range from 0.48 to 0.58. Panel B shows that timing strategies produce statistically significant alphas. Alphas range from 
$0.79 \%$ per half-year for the least aggressive timing strategy $(0.75,1.25)$ to $3.14 \%$ per half-year for the most aggressive strategy $(0,2)$.

Panel $\mathrm{C}$ of Table 3 displays active returns and information ratios. These metrics are relevant for portfolio managers who are paid to take equity risk, such as managers of mutual funds dedicated to stocks. Because the zero-risk position for such managers is a passive equity investing strategy rather than a $100 \%$ cash position, they care about return and risk relative to the passive strategy benchmark. We display the average active returns relative to this benchmark, the standard deviations of active returns relative to the benchmark (i.e., the tracking error), and the ratio of these two measures (i.e., the information ratio).

The table shows that market-timing strategies that are, on average, fully invested have significantly positive average active returns and deliver an annualized information ratio equal to $0.34 .{ }^{11}$ To put this result in perspective, note that Bossert, Füss, Rindler, and Schneider (2010) studied all actively managed U.S. equity mutual funds over the January 1998-December 2008 period and found that an annualized information ratio greater than 0.28 places a fund in the top quartile. Therefore, sell-in-May timing strategies are surprisingly competitive.

\section{How Pervasive Is the Sell-in-May Effect?}

We also studied the sell-in-May effect across a variety of additional trading strategies that appear to reap excess returns as compensation for risk taking. These results may shed light on whether the sellin-May effect is driven by widespread seasonality in the aggregate risk aversion of financial markets or by frictions that are specific to stock-versus-cash investing decisions.

We considered seven trading strategies that have been shown to produce excess returns on average; the results are shown in Table 4 . The size and value premium strategies are long-short strategies that exploit cross-sectional differences in stock returns (Fama and French 1993). The size premium strategy involves buying smallcap stocks and shorting large-cap stocks, and the value premium strategy entails buying value stocks (those with a high book-to-market ratio) and shorting growth stocks (those with a low book-to-market ratio). The data are from Ken French's website. $^{12}$

The FX carry trade premium and the equity volatility risk premium strategies are exploited by sophisticated investors, such as hedge funds and banks' proprietary desks. The FX carry trade premium strategy is a long-short strategy that invests in the money markets of high-interest-rate currencies and borrows in the money markets of low-interest-rate currencies (Lustig and Verdelhan 2007). The data are from Adrien Verdelhan's website. $^{13}$

The equity volatility risk premium strategy sells short-term at-the-money equity index options and delta hedges them until their maturity (Bakshi and Kapadia 2003). On average, it generates positive returns because, on average, implied volatility is higher than subsequent realized volatility. The data are from the Merrill Lynch Equity Volatility Arbitrage Index.

The three remaining strategies involve bonds. The corporate version of the credit risk premium strategy involves buying speculative-grade corporate bonds. The sovereign version of the credit risk premium strategy entails buying dollardenominated emerging market government bonds. The data are from the Bank of America Merrill Lynch U.S. High Yield 100 Index and the JPMorgan Emerging Market Bond Index, respectively. The term premium strategy buys long-term (maturity above 20 years) U.S. Treasury bonds. As in Fama and French (1993), excess returns on these bond strategies (as well as on the equity risk premium strategy) are calculated relative to one-month T-bills. The data are from the Fama bond portfolio returns in WRDS.

Table 4 displays estimates of the sell-in-May effect using excess returns across various trading strategies. The sample periods start either in May 1970 or when data became available. We found an economically large sell-in-May effect in six of the seven additional trading strategies: value, size, FX carry trade, equity volatility, credit risk (corporate), and credit risk (sovereign). That is, the excess returns of these strategies are much larger for November-April periods than for May-October periods. The differences in halfyear excess returns range from 3.09 pps for the value premium strategy to $5.46 \mathrm{pps}$ for the equity volatility risk premium strategy, compared with 6.46 pps for the U.S. equity risk premium strategy. In addition to being economically significant, the sell-in-May effect is also positive and statistically significant in five of the seven additional trading strategies.

The results in Table 4 indicate that the sell-inMay effect is not confined to the aggregate stock market. Rather, it is associated with widespread seasonality in aggregate risk aversion in financial markets. Moreover, because we found a sell-inMay effect in trading strategies outside the realm 
Table 4. Pervasiveness of the Sell-in-May Effect

( $t$-statistics in parentheses)

\begin{tabular}{|c|c|c|c|c|c|c|}
\hline Premium & Sample & $N$ & Overall & May-Oct. & Nov.-Apr. & $\begin{array}{c}\text { Sell-in-May } \\
\text { Effect }\end{array}$ \\
\hline $\begin{array}{l}\text { U.S. equity risk premium } \\
\text { (MSCI U.S. Equity Index) }\end{array}$ & May 1970-Apr. 2012 & 84 & $\begin{array}{c}2.84 \\
(2.25)\end{array}$ & -0.39 & 6.07 & $\begin{array}{c}6.46 \\
(3.09)\end{array}$ \\
\hline $\begin{array}{l}\text { Size premium } \\
\text { (Fama-French SMB) }\end{array}$ & May 1970-Apr. 2012 & 84 & $\begin{array}{c}1.19 \\
(1.36)\end{array}$ & -1.15 & 3.53 & $\begin{array}{c}4.68 \\
(2.93)\end{array}$ \\
\hline $\begin{array}{l}\text { Value premium } \\
\text { (Fama-French HML) }\end{array}$ & May 1970-Apr. 2012 & 84 & $\begin{array}{c}2.26 \\
(2.47)\end{array}$ & 0.71 & 3.80 & $\begin{array}{c}3.09 \\
(1.85)\end{array}$ \\
\hline $\begin{array}{l}\text { FX carry trade premium } \\
\text { (Lustig and Verdelhan) }\end{array}$ & Nov. 1983-Nov. 2011 & 56 & $\begin{array}{c}4.23 \\
(4.98)\end{array}$ & 2.39 & 6.08 & $\begin{array}{c}3.69 \\
(2.10)\end{array}$ \\
\hline $\begin{array}{l}\text { Equity volatility risk premium } \\
\text { (Merrill Lynch Equity } \\
\text { Volatility Arbitrage Index) }\end{array}$ & Apr. 1989-Apr. 2012 & 46 & $\begin{array}{c}3.37 \\
(2.02)\end{array}$ & 0.64 & 6.10 & $\begin{array}{c}5.46 \\
(1.73)\end{array}$ \\
\hline $\begin{array}{l}\text { Credit risk premium (corporate) } \\
\text { (Bank of America Merrill } \\
\text { Lynch U.S. High Yield } 100 \\
\text { Index) }\end{array}$ & Apr. 1980-Apr. 2012 & 64 & $\begin{array}{c}2.71 \\
(2.61)\end{array}$ & 0.33 & 5.09 & $\begin{array}{c}4.76 \\
(2.76)\end{array}$ \\
\hline $\begin{array}{l}\text { Credit risk premium (sovereign) } \\
\text { (JPMorgan Emerging Market } \\
\text { Bond Index) }\end{array}$ & Apr. 1994-Apr. 2012 & 36 & $\begin{array}{c}4.71 \\
(3.40)\end{array}$ & 2.63 & 6.78 & $\begin{array}{c}4.15 \\
(1.24)\end{array}$ \\
\hline $\begin{array}{l}\text { Term premium } \\
\text { (Fama bond portfolio returns, } \\
20+\text { years) }\end{array}$ & Nov. 1971-Nov. 2011 & 80 & $\begin{array}{c}1.85 \\
(2.17)\end{array}$ & 3.39 & 0.31 & $\begin{array}{l}-3.08 \\
(-2.09) \\
\end{array}$ \\
\hline
\end{tabular}

Notes: Table 4 contains estimates of the sell-in-May effect across various risky trading strategies. The table displays average excess returns (in percentages) for the November-April and May-October half-year periods as well as their differences (in pps) in the sell-in-May effect column. The $t$-statistics are based on Newey-West standard errors with one lag. Coefficients that are statistically significant at the $10 \%$ level in two-tailed tests are in bold.

of retail investors, such as the FX carry trade premium and the equity volatility risk premium, our results indicate that risk aversion seasonality affects not only retail investors but also professional market participants. ${ }^{14}$

Interestingly, we did not find a significant sell-in-May effect in the term premium; we actually found a puzzling buy-in-May effect. As in Fama and French (1993), in our study, long-term T-bond portfolios earned higher returns on average than one-month T-bills. On average over the entire year, the difference in returns is equal to 1.85 pps per half-year. However, average excess returns are actually much smaller in NovemberApril periods than in May-October periods; the difference is equal to $-3.08 \mathrm{pps}$ and is statistically significant. Perhaps the term premium is different because there may be long-term investors (e.g., pension funds) for whom long-term T-bonds, as opposed to one-month T-bills, better approximate a riskless position. To the extent that these investors are more prone to risk aversion seasonality than the average investor, their existence would influence prices in the direction of a smaller term premium in general and a term premium that is skewed upward for May-October as opposed to November-April.

\section{Conclusion}

The adage "Sell in May and go away" remains good investment advice. The sell-in-May effect persists out of sample with the same economic magnitude as in the original sample of Bouman and Jacobsen (2002): On average across markets, stock returns are about 10 pps higher for November-April than 
May-October. This out-of-sample persistence indicates that the effect is enduring and not a statistical fluke. Further, we explicitly showed that this anomaly could have been profitably exploited through investable strategies.

Moreover, the sell-in-May effect is pervasive across financial markets. It is present not only in the equity risk premium, as documented by Bouman and Jacobsen (2002), but also in the size, value, FX carry trade, equity volatility risk, and credit risk (corporate and sovereign) premiums. Therefore, widespread seasonality in financial markets' aggregate risk aversion is likely the proximate cause of the sell-in-May effect. To the extent that this seasonality is ultimately irrational, our results suggest that markets may be slower to arbitrage away inefficiencies than previously thought.

This article qualifies for 1 CE credit.

\section{Appendix A. The January Effect}

Table A1 contains aggregate estimates (in pps) of the January effect in global stock returns, defined as the difference between average monthly returns in January and in the other months.

Table A1. January Effect

( $t$-statistics in parentheses)

\begin{tabular}{lcc}
\hline $\begin{array}{l}\text { Dependent Variable: Monthly Stock Returns in } \\
\text { Local Currency (\%) }\end{array}$ & $\begin{array}{c}\text { Bouman and Jacobsen (2002) } \\
\text { Sample Period excluding } \\
\text { Argentina and Brazil }\end{array}$ & $\begin{array}{c}\text { Out of Sample: } \\
\text { Nov. 1998-Apr. 2012 }\end{array}$ \\
\hline With market fixed effects & 3.03 & 0.05 \\
January effect & $(3.58)$ & $(0.04)$ \\
PSCE & $(8.95)$ & $(0.15)$ \\
Newey-West & $(3.94)$ & $(0.04)$ \\
Driscoll-Kraay & 2.78 & -0.10 \\
January effect & $(3.35)$ & $(-0.08)$ \\
Prais-Winsten PCSE & & 0.01 \\
Without market fixed effects & 3.03 & $(0.04)$ \\
January effect & $(3.58)$ & $(0.15)$ \\
PSCE & $(9.05)$ & $(0.04)$ \\
Newey-West & $(3.92)$ & -0.11 \\
Driscoll-Kraay & 2.79 & $(-0.09)$ \\
January effect & $(3.36)$ & 37 \\
Prais-Winsten PCSE & 35 & 6,068 \\
No. of markets & 8,224 & 164 \\
No. of observations & 235 & 164 \\
Average no. of observations per market & 44 & 164 \\
Minimum no. of observations per market & 344 & \\
Maximum no. of observations per market & & \\
\hline Notes: Total returs & & \\
\hline
\end{tabular}

Notes: Total returns for MSCI indices in local currencies, expressed in percentages, are used in pooled regressions across 37 markets in which the dependent variable is the monthly index return and the independent variable is the January effect, a dummy variable equal to 1 in January and 0 otherwise. Results are shown for regressions with and without market fixed effects. The sample periods are May 1970-October 1998 (to match the Bouman and Jacobsen sample period) and November 1998-April 2012. Our regressions are either OLS or Prais-Winsten $\mathrm{AR}(1)$ regressions. The standard errors of the OLS regressions are either panel corrected (no autocorrelation), Newey-West with one lag (no cross-market correlations), or Driscoll-Kraay with one lag. The standard errors of the Prais-Winsten regressions are panel-corrected standard errors. Coefficients that are statistically significant at the $10 \%$ level (across all types of standard errors) in two-tailed tests are in bold.

\section{Notes}

1. Dzhabarov and Ziemba (2010) also investigated the sell-inMay effect, along with other seasonal anomalies. In contrast to our analysis, (1) they considered only the U.S. market, rather than all 37 markets in Bouman and Jacobsen (2002); (2) their sample period (1993-2009) overlaps nontrivially with
Bouman and Jacobsen's sample period; and (3) they did not present statistical tests.

2. For analyses of turn-of-the-month, Monday, and day-andnight effects, see, respectively, McConnell and Xu (2008); Sias and Starks (1995); Kelly and Clark (2011). 
3. Our calculations are slightly different from those of Bouman and Jacobsen (2002). We computed holding-period returns over half-year periods because it is the most natural specification given the question at hand. In contrast, Bouman and Jacobsen (2002) used continuously compounded monthly returns. Their use of monthly returns allowed them to control for the January effect, and their choice of continuous compounding ensured that arithmetic average returns within a given half-year are representative of the (per period) holding-period return over the entire half-year. However, in Table A1 of Appendix A, we show that there is no (full-market) January effect in the out-of-sample period. Therefore, we were able to proceed with the most natural specification. We checked whether all our conclusions would remain unchanged if we strictly followed the Bouman and Jacobsen (2002) specification. For example, we verified that when using the same specifications and time periods, our Table 1 results are identical to Bouman and Jacobsen's Table 1 results for all countries but South Africa, Brazil, Mexico, and the Philippines. Results for South Africa differ because we used South Africa's MSCI equity index whereas Bouman and Jacobsen used Datastream's index. The results for Brazil, Mexico, and the Philippines may not be identical because of retroactive changes to the MSCI index calculations for these three countries.

4. In specifications without fixed effects, the intercept is identical for all countries.

5. Table 1 shows that the average local-currency returns of Brazilian and Argentinian stocks in the Bouman and Jacobsen sample (for both May-October and November-April) are an order of magnitude higher than the average returns in other countries. These returns are so high because both Argentina and Brazil experienced hyperinflation at some point in Bouman and Jacobsen's sample period. Consumer price inflation in Argentina and Brazil was close to 3,000\% in 1989 and 1990, respectively.

6. Although standard OLS estimation assumes i.i.d. (independent and identically distributed) errors, the Prais-Winsten FGLS specification models the error terms as first-order serially correlated within each market.
7. PCSEs correct for cross-sectional correlation of residuals across countries but not for time-series correlation of residuals within each country. They overestimate standard errors if returns are negatively correlated over time. Newey-West standard errors correct for time-series correlation of residuals within each country but not for cross-sectional correlation of residuals across countries. They underestimate standard errors if returns are positively contemporaneously correlated across countries. Driscoll-Kraay standard errors correct for both cross-sectional correlation and time-series correlation.

8. Panel B of Table 2 also shows that we cannot reject the null hypothesis of normally distributed residuals, either in Bouman and Jacobsen's sample or out of sample. This finding is important in light of claims by some that the results in Bouman and Jacobsen (2002) are affected by outliers.

9. We used the SPDR S\&P 500 ETF and S\&P 500 Index futures, two of the most liquid equity securities in the world. For example, Justice and Rawson (2012) estimated that the market impact cost of trading $\$ 100$ million of the SPDR S\&P 500 ETF in any given day is less than $0.5 \mathrm{bp}$.

10. For simplicity, in our return calculations in Table 3, we ignored daily settlements and concentrated all S\&P 500 futures cash flows on the days the positions are unwound.

11. In contrast, the $(0,1)$ strategy has a negative active return and a large tracking error. These results indicate that the equity risk premium for May-October may be small but is positive and that being underinvested-on average over time-in equities is risky for managers who are paid to take equity risk.

12. http://mba.tuck.dartmouth.edu/pages/faculty/ken.french. 13. http://web.mit.edu/adrienv/www.

14. Two sources of seasonality in risk aversion have been proposed. Bouman and Jacobsen (2002) conjectured that seasonality is induced by vacations, but Kamstra, Kramer, and Levi (2003) proposed that it is caused by the onset of seasonal affective disorder. Both effects may play a role in generating the sell-in-May effect. Disentangling their separate influences, however, is difficult because stock return data are noisy and the separate potential sources of seasonality have correlated implications.

\section{References}

Bakshi, G., and N. Kapadia. 2003. "Delta-Hedged Gains and the Negative Volatility Risk Premium." Review of Financial Studies, vol. 16, no. 2 (April):527-566.

Bossert, T., R. Füss, P. Rindler, and C. Schneider. 2010. “How 'Informative' Is the Information Ratio for Evaluating Mutual Fund Managers?" Journal of Investing, vol. 19, no. 1 (Spring):67-81.

Bouman, S., and B. Jacobsen. 2002. "The Halloween Indicator, 'Sell in May and Go Away': Another Puzzle." American Economic Review, vol. 92, no. 5 (December):1618-1635.

Dimson, E., and P. Marsh. 1999. "Murphy's Law and Market Anomalies." Journal of Portfolio Management, vol. 25, no. 2 (Winter):53-69.

Dzhabarov, C., and W.T. Ziemba. 2010. “Do Seasonal Anomalies Still Work?" Journal of Portfolio Management, vol. 36, no. 3 (Spring):93-104.

Fama, E. 1991. "Efficient Capital Markets: II." Journal of Finance, vol. 46, no. 5 (December):1575-1617.

Fama, E., and K. French. 1993. "Common Risk Factors in the Returns of Stocks and Bonds." Journal of Financial Economics, vol. 33, no. 1 (February):3-56.
Jensen, M.C. 1978. "Some Anomalous Evidence Regarding Market Efficiency." Journal of Financial Economics, vol. 6, no. 2-3 (June-September):95-101.

Justice, P., and M. Rawson. 2012. "ETF Total Cost Analysis in Action." Morningstar ETF Research (June).

Kamstra, M.J., L.A. Kramer, and M.D. Levi. 2003. “Winter Blues: A SAD Stock Market Cycle." American Economic Review, vol. 93, no. 1 (March):324-343.

Kelly, M.A., and S.P. Clark. 2011. "Returns in Trading versus Non-Trading Hours: The Difference Is Day and Night." Journal of Asset Management, vol. 12, no. 2 (June):132-145.

Lustig, H., and A. Verdelhan. 2007. “The Cross Section of Foreign Currency Risk Premia and Consumption Risk." American Economic Review, vol. 97, no. 1 (March):89-117.

McConnell, J.J., and W. Xu. 2008. "Equity Returns at the Turn of the Month." Financial Analysts Journal, vol. 64, no. 2 (March/ April):49-64.

Rubinstein, M. 2001. "Rational Markets: Yes or No? The Affirmative Case." Financial Analysts Journal, vol. 57, no. 3 (May/June):15-29. 
Sias, R.W., and L.T. Starks. 1995. "The Day-of-the-Week Anomaly: The Role of Institutional Investors." Financial Analysts Journal, vol. 51, no. 3 (May/June):58-67.

Smalhout, J.H. 2000. "Early January: The Storied Effect on Small-Cap Stocks Now Arrives in December." Barron's (11 December):28-30.
Sullivan, R., A. Timmermann, and H. White. 2001. "Dangers of Data Mining: The Case of Calendar Effects in Stock Returns." Journal of Econometrics, vol. 105, no. 1 (November):249-286.

\section{CFA INSTITUTE BOARD OF GOVERNORS 2012-2013}

Chair

Alan M. Meder, CFA

Duff \& Phelps Investment Management Co.

Chicago, Illinois

Vice Chair

Charles J. Yang, CFA

T\&D Asset Management

Tokyo, Japan

CFA Institute President and CEO

John D. Rogers, CFA

CFA Institute

Charlottesville, Virginia

Saeed M. Al-Hajeri, CFA

Abu Dhabi Investment Authority

Abu Dhabi, United Arab Emirates

Giuseppe Ballocchi, CFA

Pictet \& Cie

Geneva, Switzerland
Beth Hamilton-Keen, CFA

Mawer Investment Management Ltd.

Calgary, Alberta, Canada

James G. Jones, CFA

Sterling Investment Advisors, LLC Bolivar, Missouri

Attila Koksal, CFA

Standard Unlu A.S.

Istanbul, Turkey

Mark J. Lazberger, CFA

Colonial First State Global Asset Management

Sydney, Australia

Frederic P. Lebel, CFA

HFS Hedge Fund Selection S.A.

Founex, Switzerland

\section{Jeffrey D. Lorenzen, CFA}

American Equity Investment

Life Insurance Co.

West Des Moines, lowa
Aaron Low, CFA

Lumen Advisors

Singapore

Colin W. McLean, FSIP

SVM Asset Management Ltd.

Edinburgh, United Kingdom

Daniel S. Meader, CFA

Trinity Private Equity Group

Southlake, Texas

Matthew H. Scanlan, CFA

RS Investments

San Francisco, California

Jane Shao, CFA

Lumiere

Beijing, China

Roger Urwin

Towers Watson

Surrey, United Kingdom 
Reproduced with permission of the copyright owner. Further reproduction prohibited without permission. 